\title{
Early Onset Escherichia coli Sepsis and Severe Intraventricular Hemorrhage in Extremely Premature Infants: Cases Series and Literature Review
}

\author{
Ipsita Goswami ${ }^{1}$, Abhay Lodha ${ }^{1}$, Stacey Dalgleish ${ }^{3}$ and Khorshid Mohammad ${ }^{1}$ \\ ${ }^{1}$ Department of Pediatrics, Cumming School of Medicine, University of Calgary, Canada \\ ${ }^{3}$ Alberta Health Services, Foothills Medical Centre, Canada
}

Submission: February 1, 2017; Published: February 23, 2017

*Corresponding author: Dr. Ipsita Goswami, Neonatal Neurocritical Care Fellow, Department of Pediatrics, Cumming School of Medicine, University of Calgary, Foothills Medical Centre, 1403 29th Street NW Calgary, Alberta, Canada Email: ipsita.goswami@ahs.ca

\begin{abstract}
Background: Widespread use of intrapartum antibiotics for Group B streptococcal prophylaxis has effectively reduced early onset gram-positive sepsis, possibly at the cost of increasing risk of Escherichia coli sepsis and its complications in very low birth weight infants. Chorioamnionitis and early onset sepsis are among the predisposing factors for germinal matrix hemorrhage, however there is a lack of reports on the emerging role of E.coli sepsis as a risk factor for intraventricular hemorrhage (IVH) compared to other organisms. Case presentation: We report a possible association between early onset resistant E. coli sepsis and severe IVH in a series of 5 preterm infants born in our regional NICU in Alberta between January and August 2015. All five infants had a history of premature rupture of membrane $>24$ hours before delivery, histological chorioamnionitis and maternal intrapartum prophylaxis with Ampicillin and Erythromycin. E-coli strains isolated from blood and CSF were resistant to empiric antibiotics commonly used in our NICU. All infants developed severe IVH (grade III/ IV) with considerable sequelae. Conclusion: Early onset E-coli sepsis in extremely premature infants may be associated with increased risk of severe IVH and subsequent white matter injury. The temporal relationship between E.coli sepsis and IVH should be further evaluated in a large prospective cohort study.
\end{abstract}

Keywords: Neonatal Sepsis; Intraventricular haemorrhage; Escherichia coli

Abbreviations: VLBWI : Very Low Birth Weight Infants; IVH: Intraventricular Hemorrhage; E.coli: Escherichia coli; GBS: Group B Streptococcal prophylaxis; EOS: Early onset sepsis; CSF: Cerebrospinal fluid

\section{Background}

Premature infants are prone to develop early sepsis because of immature immunity or may be born premature secondary to maternal intra-amniotic infection. Early onset sepsis (EOS) is defined as infection caused by bacterial pathogens, transmitted vertically from mother to infant before or during delivery, thus isolated from blood or cerebrospinal fluid (CSF) within 72 hours of birth [1]. In 2002, CDC recommended screening rectovaginal cultures of pregnant women at 35-37wks gestation and chemoprophylaxis to women positive for Group B Streptococcus (GBS) to reduce the risk of neonatal infection [2].

When delivery is imminent before a screening test is done, it has been recommended to provide GBS prophylaxis until cultures rule out GBS colonization or the infant is born. With the advent of these guidelines, the rate of EOS GBS sepsis has been effectively reduced to 0.98 per 1000 live-births while non-GBS EOS has gained predominance among the causes of mortality and morbidity, especially in premature infants. [2,3] More premature the infant is, the greater is the risk and severity of the disease. Escherichia coli has emerged as the most common cause of preterm EOS and gram-negative sepsis in neonates while GBS continues to be the commonest pathogen affecting term infants [3].

A narrow spectrum antibiotic such as Penicillin is the agent of choice for GBS prophylaxis but often in settings of preterm premature rupture of membrane (pPROM) a broadspectrum agent such as Ampicillin is used at doses that would prolong latency with adequate GBS coverage [2]. In our center, irrespective of GBS colonization status, mothers who have threatened preterm labour before $32 \mathrm{wks}$ with pPROM are given 
parenteral ampicillin and erythromycin for 48 hours followed by amoxicillin and erythromycin orally for 5 days [4]. Although effective in reducing overall incidence of EOS, administration of intrapartum broad-spectrum antibiotics has raised concerns about selective colonization by antibiotic resistant organisms [5]. In premature infants, prevention of $E$ coli EOS continues to be a challenging. $E$ coli is associated with more fulminant disease than non- $E$ coli gram-negative organisms [6]. Early onset $E$ coli sepsis in premature infants may result in systemic involvement as evidenced by thrombocytopenia and hypotension requiring aggressive interventions such as fluid boluses and inotropes, increasing the risk of germinal matrix hemorrhage in these infants. We report a possible association between early onset $E$ coli sepsis in 5 extremely preterm infants and severe intraventricular hemorrhage (IVH).

\section{Case Presentation}

We report a series of 5 very low birth weight infants (VLBWI) with early onset $E$ coli sepsis in our regional NICU between
January and August 2015. In all cases there was history of pPROM more than 24 hours prior to delivery and mothers had received intrapartum antibiotics as per unit policy and complete courses of antenatal corticosteroids. All infants had positive blood cultures growing E. coli within 12-16 hours after birth. Two cases had culture proven $E$ Coli meningitis and one had positive eye swab culture for $E$ coli as well as positive sputum cultures for the same organism. Maternal and perinatal characteristics of the infants are enumerated in Table 1. Isolated strains in cases 1-3 were resistant to Ampicillin and Ciprofloxacin but sensitive to Gentamicin and $3^{\text {rd }}$ generation cephalosporin. Twins (Case $4 \& 5$ ) were infected with multidrug resistant extended spectrum beta lactamase (ESBL) producing E.coli sensitive only to Carbapenem. E coli strains isolated from CSF were Ampicillin resistant but sensitive to cephalosporin and Carbapenem. Of three surviving infants, two were successfully treated with monotherapy of Cefotaxime and Meropenem for 10 days respectively, one was initially treated with Meropenem and later switched to Cefotaxime for 3 weeks to treat meningitis.

Table 1: Demographic Characteristics of the Cases with Clinical course and Outcome.

\begin{tabular}{|c|c|c|c|c|c|}
\hline & Case 1 & Case 2 & Case 3 & Case 4 & Case 5 \\
\hline Gestation age, weeks & $26^{+1}$ & $25^{+5}$ & $27^{+1}$ & $24^{+0}$ & $24^{+0}$ \\
\hline Birth weight, g & 785 & 750 & 1120 & 580 & 760 \\
\hline (centile) & $\left(50^{\text {th }}\right)$ & $\left(50-90^{\text {th }}\right)$ & $\left(50-90^{\text {th }}\right)$ & $\left(10-50^{\text {th }}\right)$ & $\left(50^{\text {th }}\right)$ \\
\hline Birth order & Singleton & Singleton & Singleton & Twin 1 & Twin 2 \\
\hline Maternal age (years) & 24 & 35 & 39 & 38 & 38 \\
\hline Gender & Female & Female & Female & Male & Male \\
\hline \multirow[t]{2}{*}{ Maternal infection } & $\begin{array}{l}\text { Asymptomatic } \\
\text { bacteruria }\end{array}$ & \multirow[t]{2}{*}{ None } & \multirow{2}{*}{$\begin{array}{l}\text { Group B streptococcal } \\
\text { colonization }\end{array}$} & Asymptomatic & \multirow{2}{*}{$\begin{array}{l}\text { Asymptomatic } \\
\text { bacteruria }\end{array}$} \\
\hline & E. coli UTI & & & bacteruria & \\
\hline Mode of delivery & Vaginal & Caesarean & Caesarean & Vaginal & Vaginal \\
\hline PPROM, days & 4 & 12 & 9 & 2 & 2 \\
\hline $\begin{array}{l}\text { Intrapartum } \\
\text { antibiotics, days }\end{array}$ & $<7$ & $>7$ & $>7$ & $<7$ & $<7$ \\
\hline Apgar at $5 \mathrm{~min}$ & 6 & 7 & 5 & 8 & 7 \\
\hline Chorioamnionitis & Yes & Yes & Yes & Yes & Yes \\
\hline $\begin{array}{c}\text { Duration of } \\
\text { ventilation, days }\end{array}$ & 7 & 10 & - & - & 21 \\
\hline $\begin{array}{l}\text { Parenteral Nutrition, } \\
\text { days }\end{array}$ & 9 & 13 & - & - & 15 \\
\hline $\begin{array}{l}\text { Hypotension requiring } \\
\text { ionotropes }\end{array}$ & No & No & Yes & Yes & Yes \\
\hline Significant PDA & No & Yes, Ibuprofen & Yes, not treated & Yes, not treated & Yes, Ligation \\
\hline Lowest platelet count & 122 & 45 & 49 & 22 & 58 \\
\hline Mortality & No & No & Yes (day 6) & Yes (day 12) & No \\
\hline Meningitis & No & Yes & Yes & No & No \\
\hline Antibiotics & Cefotaxime & Meropenem & Meropenem & Meropenem & Meropenem \\
\hline $\begin{array}{l}\text { Intracranial } \\
\text { Hemorrhage }\end{array}$ & Bilateral Grade II, PHH & Bilateral Grade II & $\begin{array}{c}\text { Bilateral Grade III \& } \\
\text { cerebellar }\end{array}$ & $\begin{array}{c}\text { Grade II (Rt) \& Grade } \\
\text { IV (Lt) }\end{array}$ & $\begin{array}{c}\text { Grade II (Rt) \& Grade } \\
\text { IV (Lt) }\end{array}$ \\
\hline $\begin{array}{l}\text { Periventricular } \\
\text { Leukomalacia }\end{array}$ & Rt frontal lobe cyst & No & $\begin{array}{l}\text { Non-cystic } \\
\text { echogenicity }\end{array}$ & No & Bilateral cystic \\
\hline
\end{tabular}


Abbreviations: IVH: Intraventricular Hemorrhage; PDA: Patent Ductus Arteriosus; UTI: Urinary Tract Infection; PPROM: Prolonged Premature Rupture of Membrane; Rt: Right; Lt: Left; $\mathrm{PHH}$ : Post Hemorrhagic Hydrocephalus.

All the infants developed IVH in the first week of life. Case 3 \& 4 had severe septic shock syndrome along with Grade III/IV IVH and cerebellar hemorrhages, thus care was withdrawn with parental consent. Case 1 had bilateral Grade II IVH complicated with post-hemorrhagic hydrocephalus. Of note, this infant had a relatively uneventful stay with invasive ventilation for 7 days, was on full enteral feeds by 10 days, neither had meningitis, thrombocytopenia nor medical management of patent ductus arteriosus (PDA). The post-hemorrhagic hydrocephalus was initially managed with a reservoir and serial CSF tapping and later required choroid plexus coagulation and $3^{\text {rd }}$ ventriculostomy followed by ventriculo-peritoneal shunt placement. Case 5 had progressive ventricular dilatation during NICU stay that stabilised at corrected term gestational age, thus did not require invasive management. Case $1 \& 5$ had white matter injury manifested as porencephalic cysts while Case 3 had no noted complications of IVH (Figure 1).

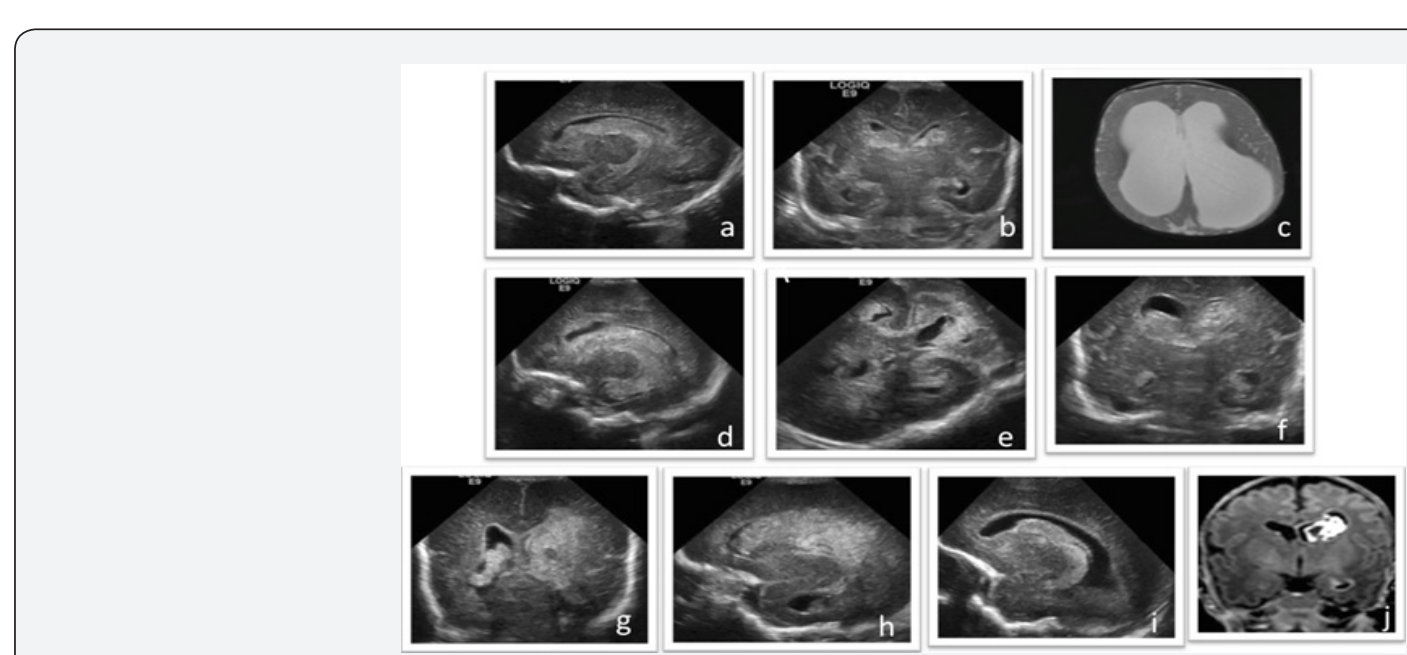

Figure 1: (a,b) Case 1 Bilateral grade II IVH on US, (c) Case 1 post-hemorrhagic hydrocephalus on MRI, (d,e,f) Case 3 Bilateral grade III IVH with cerebellar hemorrhage. (g,h,i) Case 5 right sided grade IV IVH and left sided grade II IVH and left sided Grade II IVH, (j) Case 5 Porencephalic cyst on MRI.

\section{Discussion}

Our findings suggest that antibiotic resistant $E$ coli vertically transmitted from mothers can particularly affect the immature brain and may associated with an increased risk of severe IVH. A cluster of 5 cases within a span of 6 months raises concern about changing trends in microbiological pattern of EOS and antibiotic sensitivity pattern. There is an emerging trend towards organisms resistant to empirical antibiotics used in NICU. Severe systemic infection and resulting cytokine response may lead to germinal matrix bleeds especially in the first $48 \mathrm{hrs}$ of life when the culture sensitivity of the infecting organism is pending. With the initiation of antibiotics specific to the particular organism, the systemic infection can be promptly treated and controlled but severe intraventricular hemorrhages that have occurred within first 48 hrs may have major effect on future neurological outcome among survivors.

Overall incidence of EOS in infants $<1500 \mathrm{~g}$ is 10 per 1000 live births. $E$ coli is the pathogen in 5 per 1000 , significantly more than GBS (2 per 1000) [3]. Use of intrapartum antibiotics for prevention of GBS sepsis has led to reduction in EOS but $E$ coli still accounts for $30 \%$ of the disease burden [3]. Broad-spectrum antibiotics given to mothers with pPROM reduces neonatal morbidities [7] but there is a potential problem of significant increase in Ampicillin resistant $E$ coli causing more fulminant disease especially in mothers with an intrapartum fever [8]. We report a series of five infants born before 28wks to mothers who had pPROM and developed EOS with $E$ coli resistant to the empirical antibiotics used in NICU. Certain clinical signs like intrapartum fever and pPROM $>2$ days may help identify the mothers who need to be screened for $E$ coli so that culture sensitivity is available for the suspected organism even before the infant is born.

All $E$ coli isolates in our case series were resistant to Ampicillin and Ciprofloxacin and two strains were ESBL producing organism resistant to all antibiotics except Carbapenem. Mothers of infants did not visit known countries where there is an increased risk of ESBL producing organisms. Whether use of broad-spectrum antibiotic prophylaxis has increased the risk of resistant $E$ coli infection is still controversial [5,6,8-10]. Alarmingly, all isolates in our case series were Ampicillin resistant while the empirical antibiotic used in our NICU was Ampicillin with an aminoglycoside. Fortunately, most of the isolates were Gentamicin sensitive but due to the severity of illness clinicians opted to treat with Carbepenem in 3/5 cases. Choice of empirical antibiotics that provides adequate $E$ coli coverage may be vital in this scenario as the culture sensitivity takes at-least 48 hours after birth, a time period very critical for the immature brain. 
The majority of IVH occurs within first 72 hours of life and all infants in our series developed moderate to severe IVH. Association between $E$ coli sepsis and IVH is unclear. Tsai et al. found no difference in the incidence of IVH in neonates with $E$. Coli sepsis compared to uninfected controls of same gestational age.
[6] A retrospective study identified all $E$ coli EOS cases and found $27 \%$ had IVH while $33 \%$ of the survivors assessed at infancy had impaired motor development, abnormal cognitive outcome and seizure disorders. [11] Clinical outcome of infants with E coli EOS from previously published studies are summarized in Table 2.

Table 2: Review of reported cases.

\begin{tabular}{|c|c|c|c|c|c|c|c|}
\hline Study & Type of Study & Number & $\begin{array}{c}\text { Study } \\
\text { Population }\end{array}$ & $\begin{array}{c}\text { Maternal } \\
\text { Characteristics }\end{array}$ & $\begin{array}{c}\text { Neonatal } \\
\text { Characteristics }\end{array}$ & $\begin{array}{l}\text { Antibiotic } \\
\text { Resistance }\end{array}$ & $\begin{array}{l}\text { Clinical } \\
\text { Outcome }\end{array}$ \\
\hline Stoll et al. 1996 & $\begin{array}{l}\text { Database } \\
\text { research } \\
1991-93\end{array}$ & 24 & $\begin{array}{c}\text { VLBW <1500g: } \\
7606 \\
\text { EOS 19/1000LB } \\
\text { GBS } 31 \% \\
\text { E. coli } 16 \%\end{array}$ & $\begin{array}{l}31 \% \text { mothers } \\
\text { had IA } \\
36 \% \text { of infants } \\
\text { with EOS had } \\
\text { ROM < } 6 \mathrm{hr}\end{array}$ & $\begin{array}{c}\text { GA }<28 w k s \\
\text { twice the risk } \\
\text { of EOS } \\
\text { Odds of severe } \\
\text { IVH in EOS } 2.65 \\
(1.76-3.98)\end{array}$ & $\begin{array}{c}\text { Variability } \\
\text { in antibiotic } \\
\text { administration }\end{array}$ & $\begin{array}{c}\text { Mortality } 18 \% \\
\text { Death }<72 \\
\text { hours } 12 \%\end{array}$ \\
\hline Stoll et al. 2002 & $\begin{array}{c}\text { Database } \\
\text { research } \\
1998-2000\end{array}$ & 37 & $\begin{array}{c}\text { VLBW <1500g: } \\
5447 \\
\text { EOS } 15 / 1000 \mathrm{LB} \\
\text { GBS } 10 \% \\
\text { E. coli } 44 \%\end{array}$ & $\begin{array}{l}65 \% \text { of mothers } \\
\text { had IA, } 81 \% \text { of } \\
\text { mothers were } \\
\text { infants had } E \text {. coli } \\
\text { sepsis had IA } \\
41 \% \text { of infants } \\
\text { with EOS had } \\
\text { ROM <6 hr }\end{array}$ & $\begin{array}{c}\text { GA }<28 \text { wks } \\
\text { twice the risk } \\
\text { of EOS } \\
\text { Odds of severe } \\
\text { IVH or PVL in } \\
\text { EOS } 3.2(1.9-5.5)\end{array}$ & $\begin{array}{l}\text { Ampicillin } \\
\text { resistant E. coli } \\
85 \% \\
\text { Gentamicin } \\
\text { resistant 3\% }\end{array}$ & $\begin{array}{c}\text { Mortality } 37 \% \\
\text { Death }<72 \\
\text { hours } 20 \%\end{array}$ \\
\hline Tsai et al. 2012 & $\begin{array}{l}\text { Retrospective } \\
\text { chart review, } \\
\text { single center, } \\
2004-2008, \\
\text { Case-control }\end{array}$ & 19 & $\begin{array}{l}\text { All infants with } \\
\text { sepsis within } 7 \\
\text { days of life, } 46\end{array}$ & $\begin{array}{c}74 \% \text { of E. coli } \\
\text { sepsis had PROM, } \\
47 \% \text { for }>24 \mathrm{hr}, \\
53 \% \text { had vaginal } \\
\text { delivery, } 63 \% \\
\text { had sepsis on } \\
\text { day } 1,20 \% \text { had } \\
\text { intrapartum } \\
\text { fever and } \\
\text { chorioamnionitis, }\end{array}$ & $\begin{array}{c}47 \% \text { of } E \text {. coli } \\
\text { sepsis was in } \\
\text { infants }<30 \mathrm{wks} \\
\text { and }<1500 \mathrm{~g}\end{array}$ & $\begin{array}{l}\text { 79\% Ampicillin } \\
\text { and } 16 \% \\
\text { Gentamicin } \\
\text { resistant } E \text {. coli, } \\
\text { none resistant } \\
\text { to } 3^{\text {rd }} \text { generation } \\
\text { cephalosporin }\end{array}$ & $\begin{array}{l}16 \% \text { of } E \text {. coli } \\
\text { sepsis had } \\
\text { IVH, } 21 \% \text { had } \\
\text { meningitis, } \\
32 \% \text { died }\end{array}$ \\
\hline $\begin{array}{l}\text { Bergin et } \\
\text { al.2015 }\end{array}$ & $\begin{array}{c}\text { Database search, } \\
2012\end{array}$ & 109 & $\begin{array}{l}\text { All cases of } E \text {. } \\
\text { coli positive } \\
\text { blood cultures, } \\
\text { 267, EOS } 42 \% \\
\text { of cases, }\end{array}$ & $\begin{array}{l}56 \% \text { of mothers } \\
\text { received IA, } \\
\text { higher proportion } \\
\text { of mothers } \\
\text { received IA } \\
\text { in ampicillin } \\
\text { resistant than } \\
\text { sensitive group }\end{array}$ & $\begin{array}{l}60 \% \text { of cases of } \\
\text { E. coli sepsis in } \\
\text { infants }<1500 \mathrm{~g} \\
\text { and } 68 \% \text { in }<32 \\
\text { wks infant }\end{array}$ & $\begin{array}{c}9 \text { ESBL } \\
\text { organism, } \\
\text { 49\% Ampicillin } \\
\text { resistant } E \text {. coli } \\
\text { in EOS }\end{array}$ & Mortality 21\% \\
\hline Jones et al. 2004 & $\begin{array}{c}\text { Laboratory } \\
\text { database }\end{array}$ & 20 & $\begin{array}{c}\text { All positive E. } \\
\text { coli blood and } \\
\text { CSF cultures <7 } \\
\text { days }\end{array}$ & $\begin{array}{l}50 \% \text { had PPROM, } \\
25 \% \text { had } \\
\text { intrapartum fever, } \\
\text { Of the infants } \\
\text { with amoxicillin } \\
\text { resistant E. coli, } \\
91 \% \text { of mothers } \\
\text { received IA }\end{array}$ & $\begin{array}{c}\text { Median GA } 29 \\
\text { wks and BW } \\
1045 \mathrm{~g}, 72 \% \\
\text { were born } \\
<32 \text { wks }\end{array}$ & $\begin{array}{l}55 \% \\
\text { amoxicillin, } \\
\text { and } 5 \% \text { were } \\
\text { gentamicin } \\
\text { resistant. }\end{array}$ & $\begin{array}{c}\text { Meningitis } 40 \% \\
\text { Mortality } 40 \% \text {, } \\
\text { IVH } 27 \% \\
\text { Abnormal } \\
\text { neurological } \\
\text { exam at } \\
\text { 6months 33\% }\end{array}$ \\
\hline $\begin{array}{l}\text { JFriedman et al. } \\
\qquad 2000\end{array}$ & $\begin{array}{c}\text { Laboratory data } \\
\text { base search, } \\
1994-98\end{array}$ & 4 & $\begin{array}{l}\text { All infants with } \\
\text { E. coli positive } \\
\text { culture within } \\
28 \text { d, } \\
\text { Total } 23 \text {, } \\
\text { EOS } 17 \%\end{array}$ & $\begin{array}{c}47 \% \text { of total cases } \\
\text { had PROM, } 26 \% \\
\text { mothers received } \\
\text { IA }\end{array}$ & $\begin{array}{l}\text { Median GA } 29 \\
(24-40) \text { wks } \\
\text { and BW 1045 } \\
(610-3945) \mathrm{g}, \\
\text { 72\% were born } \\
\text { <32wks, }\end{array}$ & $\begin{array}{l}\text { 75\% Ampicillin } \\
\text { and 50\% } \\
\text { Gentamicin } \\
\text { resistant in EOS } \\
\text { group }\end{array}$ & Mortality 34\% \\
\hline
\end{tabular}




\begin{tabular}{|c|c|c|c|c|c|c|c|}
\hline $\begin{array}{l}\text { Shrag et al. } \\
2006\end{array}$ & $\begin{array}{c}\text { Retrospective } \\
\text { case-control } \\
\text { study, 1997-2001 }\end{array}$ & 132 & $\begin{array}{l}\text { Cases infants }< \\
\text { 7Cases infants } \\
<7 \mathrm{~d} \text { with } \\
\text { positive blood/ } \\
\text { CSF E. coli } \\
\text { culture } \\
\text { Cases } 132 \\
\text { Control } 1212\end{array}$ & $\begin{array}{c}53 \% \text { cases } \\
\text { exposed to IA, } \\
20 \% \text { of cases had } \\
\text { intrapartum fever, } \\
45 \% \text { had ROM }>18 \\
\text { hrs. }\end{array}$ & $\begin{array}{c}48 \% \text { of cases } \\
<33 \mathrm{wks}, 47 \% \\
<1500 \mathrm{~g}\end{array}$ & $\begin{array}{l}59 \% \text { of cases } \\
\text { had Ampicillin } \\
\text { resistant strain, }\end{array}$ & $\begin{array}{l}\text { Mortality 16\%, } \\
\text { Meningitis 9\% }\end{array}$ \\
\hline $\begin{array}{l}\text { Bizarro et al. } \\
\quad 2008\end{array}$ & $\begin{array}{l}\text { Retrospective } \\
\text { chart review } \\
\text { Period 1(1979- } \\
\text { 92): Before GBS } \\
\text { prophylaxis } \\
\text { guideline, } \\
2(1993-96): \\
\text { risk factor based } \\
\text { treatment } \\
\text { 3(1997-2006): } \\
\text { screening based } \\
\text { treatment }\end{array}$ & 53 & $\begin{array}{c}\text { All infants with } \\
\text { sepsis, Total } \\
1385 \\
\text { EOS } 17 \% \\
\text { LOS } 83 \% \\
\text { E. coli sepsis } \\
13 \%\end{array}$ & $\begin{array}{l}\text { Proportion of } \\
\text { infants delivered } \\
\text { after preterm } \\
\text { labor (period 1: } \\
50 \% \text {, period 2: } \\
75 \% \text {, period 3: } \\
\text { 82\%), PROM } \\
\text { (period 1: } \\
\text { 50\%, period 2: } \\
50 \% \text {, period } \\
\text { 3: 44\%), and } \\
\text { chorioamnionitis } \\
\text { (period 1: } 0 \% \text {, } \\
\text { period 2:: }\end{array}$ & $\begin{array}{l}50 \% \text { of EOS E. } \\
\text { coli sepsis in } \\
\text { VLBWI }\end{array}$ & $\begin{array}{l}\text { In period } 1, \\
20 \% \text { of cases } \\
\text { were ampicillin- } \\
\text { resistant, IN } \\
\text { period } 244 \% \\
\text { andPeriod } 3 \\
54 \%\end{array}$ & $\begin{array}{c}\text { Meningitis 10\% } \\
\text { Mortality } 26 \%\end{array}$ \\
\hline
\end{tabular}

Abbreviations: GA: Gestational Age; BW: Birth Weight; pPROM: Preterm Premature Rupture of Membrane; IVH: Intraventricular Hemorrhage; EOS, Early Onset Sepsis; LOS: Late Onset Sepsis; IA: Intrapartum Antibiotics.

Among the studies that have reported the clinical characteristics of $E$ coli sepsis, only two studies mention the incidence of IVH ranging from $15-30 \%$ and only one reports longterm outcome. Systemic inflammation either intrauterine or within the first week of life increases the likelihood of IVH in extreme premature infants $[12,13]$. The other organism, associated with higher risk IVH is Ureaplasma Urealyticum colonizing maternal genital tract [14]. Given the fact that $E$ coli is a more virulent organism, we speculate that the virulence of the pathogen is an important trigger for severe inflammatory response and possibly causing severe intraventricular haemorrhage [15].

E coli EOS may lead to increased risk of IVH directly as well as secondary to associated thrombocytopenia and coagulopathy, which increases the propensity to bleed. Lower platelet count during first 3 days of life increases the risk of IVH in VLBWI with gram negative EOS [16]. The effect of neonatal sepsis on platelet count is believed to be organism specific, the platelet nadir being significantly of lower in gram-negative sepsis [15]. Four cases in our case series had significant thrombocytopenia in the first week of life requiring transfusions. Affected infants are more likely to receive volume expanders due to hypotension and have a hemodynamically significant PDA contributing to the fluctuations in cerebral blood flow. Premature infants with their limited capacity of cerebral autoregulation, further impaired by systemic illness, are unable to buffer the effect of fluctuations leading to germinal matrix hemorrhage [17].

\section{Conclusion}

We report a possible association between early onset Ampicillin resistant $E$ coli infection and IVH in VLBWI. There is need of continued surveillance to monitor changes in sensitivity pattern of pathogens causing EOS in NICU and emergence of strains resistant to the antibiotics used for antepartum prophylaxis.
Clinicians need to be aware of the risk factors that precede $E$ coli sepsis and its implications on VLBWI. Timely interventions like aggressive antimicrobial therapy, platelet transfusions and early PDA closure may reduce the risk of severe IVH. Further prospective studies would be needed to establish temporal relationship.

\section{Author's Contributions}

IG performed literature search and started writing the manuscript. KM conceived the idea, obtained results, manuscript revision, and pictures. AL contributed to manuscript, finalized the manuscript. SD did critical analysis of the manuscript and obtaining consent for publication. All the authors read and approved the final manuscript.

\section{Consent}

Written consent was obtained from parents in institutional forms for publication of data.

\section{Competing Interests}

The authors declare that they have no competing interests. We acknowledge advice from Stephen L Wood, MD, Associate Professor, Department of Obstetrics \& Gynaecology, during the preparation of the manuscript.

\section{References}

1. Wortham JM, Hansen NI, Schrag SJ, Hale E, Van Meurs K, et al. (2016) Chorioamnionitis and Culture-Confirmed, Early-Onset Neonatal Infections. Pediatrics 137(1): 1-11.

2. Verani JR, McGee L, Schrag SJ (2010) Prevention of perinatal group B streptococcal disease--revised guidelines from CDC. Recommendations and Reports 59(Rr-10): 1-36.

3. Stoll BJ, Hansen NI, Sanchez PJ, Faix RG, Poindexter BB, V, et al. (2011) Early onset neonatal sepsis: the burden of group B Streptococcal and E. coli disease continues. Pediatrics 127(5): 817-826. 
4. Yudin MH, van Schalkwyk J, Van Eyk N, Boucher M, Castillo E, et al. (2009) Antibiotic therapy in preterm premature rupture of the membranes. J Obstet Gynaecol Can 31(9): 863-867, 868-874.

5. Bizzarro MJ, Dembry LM, Baltimore RS, Gallagher PG (2008) Changing patterns in neonatal Escherichia coli sepsis and ampicillin resistance in the era of intrapartum antibiotic prophylaxis. Pediatrics 121(4): 689696.

6. Tsai CH, Chen YY, Wang KG, Chen CY, Chen CP (2012) Characteristics of early-onset neonatal sepsis caused by Escherichia coli. Taiwan J Obstet Gynecol 51(1): 26-30.

7. Kenyon S, Boulvain M, Neilson JP (2010) Antibiotics for preterm rupture of membranes. Cochrane Database Syst Rev, doi: 10.1002/14651858. CD001058.

8. Joseph TA, Pyati SP, Jacobs N (1998) Neonatal early-onset Escherichia coli disease. The effect of intrapartum ampicillin. Arch Pediatr Adolesc Me 152(1): 35-40.

9. Schrag SJ, Hadler JL, Arnold KE, Martell-Cleary P, Reingold A, et al (2006) Risk factors for invasive, early-onset Escherichia coli infections in the era of widespread intrapartum antibiotic use. Pediatrics 118(2): 570-576.

10. Bergin SP, Thaden JT, Ericson JE, Cross H, Messina J, et al. (2015) Neonatal Escherichia coli Bloodstream Infections: Clinical Outcomes and Impact of Initial Antibiotic Therapy. Pediatr Infect Dis J 34(9): 933936.
11. Jones B, Peake K, Morris AJ, McCowan LM, Battin MR (2004) Escherichia coli: a growing problem in early onset neonatal sepsis. Aust N Z J Obstet Gynaecol 44(6): 558-561.

12. Moscuzza F, Belcari F, Nardini V, Bartoli A, Domenici C, et al. (2011) Correlation between placental histopathology and fetal/ neonatal outcome: chorioamnionitis and funisitis are associated to intraventricular haemorrage and retinopathy of prematurity in preterm newborns. Gynecol Endocrinol 27(5): 319-323.

13. Heep A, Behrendt D, Nitsch P, Fimmers R, Bartmann P, et al. (2003) Increased serum levels of interleukin 6 are associated with severe intraventricular haemorrhage in extremely premature infants. Arch Dis Child Fetal Neonatal Ed 88(6): F501-F504.

14. Olomu IN, Hecht JL, Onderdonk AO, Allred EN, Leviton A (2009) Perinatal correlates of Ureaplasma urealyticum in placenta parenchyma of singleton pregnancies that end before 28 weeks of gestation. Pediatrics 123(5): 1329-1336.

15. Guida JD, Kunig AM, Leef KH, McKenzie SE, Paul DA (2003) Platelet count and sepsis in very low birth weight neonates: is there an organism-specific response? Pediatrics 111(6 Pt 1): 1411-1415.

16. Mitsiakos G, Pana Z-D, Chatziioannidis I, Piltsouli D, Lazaridou E, et al. (2015) Platelet Mass Predicts Intracranial Hemorrhage in Neonates With Gram-negative Sepsis. J Pediatr Hematol Oncol 37(7): 519-523.

17. Wong FY, Silas R, Hew S, Samarasinghe T, Walker AM (2012) Cerebral oxygenation is highly sensitive to blood pressure variability in sick preterm infants. PLoS One 7(8): e43165.

\section{Your next submission with Juniper Publishers will reach you the below assets}

- Quality Editorial service

- Swift Peer Review

- Reprints availability

- E-prints Service

- Manuscript Podcast for convenient understanding

- Global attainment for your research

- Manuscript accessibility in different formats ( Pdf, E-pub, Full Text, Audio)

- Unceasing customer service

Track the below URL for one-step submission https://juniperpublishers.com/online-submission.php 